\title{
IMPLEMENTASI KEBIJAKAN PERATURAN PEMERINTAH NOMOR 11 TAHUN 2017 TENTANG MANAJEMEN PEGAWAI NEGERI SIPIL (Studi Penelitian Mengenai Pejabat Fungsional Penyuluh Pertanian pada Dinas Pertanian dan Pangan Kabupaten Badung)
}

\author{
Putu Mariani ${ }^{1}$, I Made Sumada ${ }^{2}$ \\ ${ }^{1}$ Pascasarjana Magister Administrasi Publik, Universitas Ngurah Rai; \\ email : \\ ${ }^{21}$ Pascasarjana Magister Administrasi Publik, Universitas Ngurah Rai; \\ email :sumadaimade@gmail.com
}

\begin{abstract}
This study aimed to determine the Implementation of PP Policy No. 11 of 2017 concerning Management of Civil Servants, particularly against Functional Officers of Agricultural Extension Workers in Badung Expected and to find out the constraints faced and solutions in the Implementation of PP Policy No. 11 of 2017 concerning Management of Civil Servants, especially towards Officials Functional Agriculture Instructor at Dikpa Badung. This research was a qualitative descriptive study. Samples were taken by using purposive sampling technique. Data collection methods are by interview, observation and documentation. The data obtained were then analyzed descriptively. The research result was that the Implementation of Government Regulation Number 11 Year 2017 regarding Management of Civil Servants, especially for Agricultural Extension Functional Officials in Dikpa Badung, was not fully running well because there were several obstacles encountered / problems. 2) Constraints in the Implementation of Government Regulation Number 11 Year 2017 concerning Management of Civil Servants, particularly for Agricultural Extension Functional Officials in Dikpa Badung, among others: Number of functional agricultural extension officers who are still lacking; BUP of Functional Officers has been misinterpreted; Constraints in the promotion process related to the value of credit numbers; Constraints in the transfer process; Civil servant movements; The Agriculture Extension JF formation has not been made yet. 3) Solutions to overcome obstacles in the Implementation of Government Regulation Number 11 Year 2017 concerning Management of Civil Servants, especially for Agricultural Extension Functional Officials in Dikpa Badung, among others: lifting contract extension workers; coordination between related parties, so that only one interpretation will arise, speeding up the credit score assessment proposal while maintaining the quantity and quality of the proposed credit so that the value set by the Credit Score Assessment Team was sufficient for the promotion process; provide education and training budgets for level shifting for agricultural extension workers who are budgeted through the Badung Regency APBD; if you were
\end{abstract}


going to carry out a civil servant mutation, BKPSDM Badung Regency must first coordinate with Dikpa Badung; immediately arrange the formation of the Dikpa Badung for the needs of agricultural extension functional officials at that level and also at the same time formulate the formation of the Dikpa Badung for the needs of agricultural extension functional functional officials in full.

Keywords: management, PP Number 11 of 2017, civil servants, agricultural extension workers.

\begin{abstract}
Abstrak
Penelitian ini bertujuan untuk mengetahui Implementasi Kebijakan PP Nomor 11 Tahun 2017 tentang Manajemen PNS, khususnya terhadap Pejabat Fungsional Penyuluh Pertanian pada Diperpa Badung dan untuk mengetahui kendala-kendala yang dihadapi serta solusi dalam Implementasi Kebijakan PP Nomor 11 Tahun 2017 tentang Manajemen PNS, khususnya terhadap Pejabat Fungsional Penyuluh Pertanian pada Diperpa Badung. Penelitian ini merupakan penelitian deskriptif kualitatif. Sampel diambil dengan menggunakan Teknik purposive sampling. Metode pengambilan data adalah dengan wawancara, observasi dan dokumentasi. Data yang diperoleh kemudian dianalisis secara deskriptif. Adapaun hasil penelitian adalah Implementasi PP Nomor 11 Tahun 2017 tentang Manajemen PNS, khususnya terhadap Pejabat Fungsional Penyuluh Pertanian pada Diperpa Badung, tidak sepenuhnya berjalan dengan baik terdapat karena ditemukan beberapa kendala/permasalahan. 2) Kendala dalam Implementasi PP Nomor 11 Tahun 2017 tentang Manajemen PNS, khususnya terhadap Pejabat Fungsional Penyuluh Pertanian pada Diperpa Badung, antara lain : Jumlah pejabat fungsional penyuluh pertanian yang masih kurang; BUP Pejabat Fungsional banyak disalahtafsirkan; Kendala dalam proses kenaikan pangkat terkait nilai angka kredit; Kendala dalam proses alih jenjang; Mutasi PNS; Belum dibuat formasi JF Penyuluh Pertanian. 3) Solusi untuk mengatasi kendala dalam Implementasi PP Nomor 11 Tahun 2017 tentang Manajemen PNS, khususnya terhadap Pejabat Fungsional Penyuluh Pertanian pada Diperpa Badung, antara lain : mengangkat tenaga penyuluh pertanian kontrak; koordinasi antar para pihak terkait, sehingga akan timbul satu penafsiran saja, mempercepat usulan penilaian angka kredit dengan tetap menjaga kuantitas dan kualitas kredit yang diajukan sehingga nilai yang ditetapkan oleh Tim Penilai Angka Kredit cukup untuk proses kenaikan pangkat; menyediakan anggaran pendidikan dan pelatihan alih jenjang bagi penyuluh pertanian yang dianggarkan melalui APBD Kabupaten Badung; jika akan melaksanakan mutasi PNS, BKPSDM Kabupaten Badung harus melakukan koordinasi terlebih dahulu dengan Diperpa Badung; segera menyusun formasi pada Diperpa Badung untuk kebutuhan pejabat fungsional penyuluh pertanian pada jenjang tersebut dan juga sekaligus menyusun formasi pada Diperpa Badung untuk kebutuhan pejabat fungsional penyuluh pertanian secara lengkap.; (b) Kendala dari aaspek Sumber Daya Manusia (SDM); dan (c) Kendala dari aspek Disposisi.
\end{abstract}

Kata Kunci: manajemen, PP Nomor 11 Tahun 2017, PNS, penyuluh pertanian

\title{
I. PENDAHULUAN
}

\subsection{Latar Belakang Masalah}

Pertanian merupakan sektor yang sangat penting dalam perekonomian nasional. Pembangunan ekonomi masih akan tetap berbasis pertanian secara luas. Namun, sejalan dengan tahapan-tahapan perkembangan ekonomi maka kegiatan jasa-jasa dan bisnis berbasis pertanian juga akan semakin meningkat, dengan kata lain kegiatan agribisnis akan menjadi salah satu kegiatan unggulan pembangunan 
ekonomi nasional dalam berbagai aspek yang luas.Penyuluhan pertanian sebagai bagian integral pembangunan pertanian merupakan salah satu upaya pemberdayaan petani dan pelaku usaha pertanian lain untuk meningkatkan produktivitas, pendapatan dan kesejahteraannya. Untuk itu kegiatan penyuluhan pertanian harus dapat mengakomodasikan aspirasi dan peran aktif petani dan pelaku usaha pertanian, lainnya melalui pendekatan partisipatif. Pengembangan pembangunan pertanian di masa mendatang perlu memberikan perhatian yang khusus terhadap penyuluhan pertanian, karena penyuluhan pertanian merupakan salah satu kegiatan yang strategis dalam upaya pencapaian tujuan pembangunan pertanian. Melalui kegiatan penyuluhan, petani ditingkatkan kemampuannya agar dapat mengelola usaha taninya dengan produktif, efisien dan menguntungkan, sehingga petani dan keluarganya dapat meningkatkan kesejahteraanya. Meningkatnya kesejahteraan petani dan keluarganya adalah tujuan utama dari pembangunan pertanian.

Mosher (1981) mengemukakan bahwa untuk mempercepat pembangunan pertanian setiap petugas perlu terus diberi kesempatan untuk belajar mengembangkan keterampilan-keterampilan baru dan meningkatkan keahlian khusunya selama ia masih aktif dalam jabatannya. Karena salah satu upaya peningkatan kapasitas SDM pertanian adalah salah satu cara untuk meningkatkan kesejahteraan petani kecil. SDM pertanian yang dimaksud di atas, selain petani juga aparaturnya yang didalamnya termasuk penyuluh pertanian. Pemerintah Kabupaten Badung (Pemkab Badung) memiliki komitmen untuk menyelaraskan pertumbuhan sektor pertanian dengan sektor pariwisata. Mengingat selama lima tahun terakhir, pertumbuhan sektor pertanian dengan pariwisata di Kabupaten Badung itu belum sejalan. Banyaknya alih fungsi lahan, bukti sektor pertanian belum menjanjikan. Untuk mewujudkan hal tersebut, Pemkab Badung melalui Dinas Pertanian dan Pangan Kabupaten Badung (Diperpa Badung) menyelengggarakan program dan kegiatan yang dianggarkan dari Anggaran Pendapatan dan Belanja Daerah (APBD) khusus di bidang pertanian yang meliputi tanaman pangan hortikultura, perkebunan, peternakan, sarana prasarana pertanian, penyuluhan pertanian dan ketahanan pangan. serta didukung oleh SDM yang profesional di bidang pertanian terutamanya adalah tenaga penyuluh pertanian. 
Salah satu program yang diselenggarakan oleh Diperpa Badung yang terkait langsung dengan keberadaan penyuluh pertanian adalah pemberdayaan penyuluh pertanian lapangan yang mencakup beberapa kegiatan antara lain :

1) Pengelolaan Balai Penyuluh Pertanian (BPP) yang meliputi 5 BPP yaitu BPP Petang, BPP Abiansemal, BPP Mengwi dan BPP Kuta Selatan.

2) Pengadaan Sarana Prasarana Penyuluh.

3) Penilaian Angka Kredit bagi Pegawai Fungsional.

4) Bimbingan Teknis Penyuluh Lapangan.

Kegiatan-kegiatan tersebut dilaksanakan berkelanjutan setiap tahun dan dalam pelaksanaannya dikoodinasikan oleh Bidang Pangan dan Penyuluhan Diperpa Badung. Seperti tercantum dalam klausul menimbang pada Keputusan Bupati Badung Nomor 52/048/HK/2019 tentang Penunjukan Tenaga Kerja Non Pegawai pada Kegiatan Pengadaan Sarana Prasarana Penyuluh, dimana disebutkan bahwa dalam rangka pembangunan pertanian yang tangguh perlu adanya dukungan SDM bidang pertanian yang profesional, sehingga perlu menunjuk tenaga kerja non pegawai sebagai Penyuluh Pertanian.

Selain pejabat fungsional yang berstatus PNS dan para tenaga penyuluh pertanian kontrak, juga didukung oleh para Tenaga Harian Lepas Tenaga Bantu Penyuluh Pertanian (THL-TBPP) sebanyak 16 orang. Hal ini tertuang dalam Keputusan Kepala Diperpa Badung Nomor 25 Tahun 2019 tentang Penetapan THL-TBPP di Kabupaten Badung Tahun Anggaran 2019, dan dalam kausul menimbang disebutkan bahwa untuk membantu lancarnya pelaksanaan penyuluhan dan pemberdayaan tenaga penyuluh Diperpa Badung serta program-program pertanian di Kabupaten Badung, maka perlu adanya THL-TBPP.

Tabel 1.1

Data Penyuluh Pertanian Tahun 2019

Berdasarkan Lokasi Penugasan Per Kecamatan

\begin{tabular}{|c|l|c|c|c|c|}
\hline \multirow{2}{*}{ No. } & $\begin{array}{l}\text { Lokasi } \\
\text { Penugasan } \\
\text { (Kecamatan) }\end{array}$ & $\begin{array}{c}\text { Pejabat } \\
\text { Fungsional }\end{array}$ & $\begin{array}{c}\text { THL- } \\
\text { TBPP }\end{array}$ & $\begin{array}{c}\text { Penyuluh } \\
\text { Kontrak }\end{array}$ & Jumlah \\
\cline { 3 - 5 } & & & & \\
\hline
\end{tabular}




\begin{tabular}{|c|l|r|r|r|r|}
\hline 1 & $\begin{array}{l}\text { Kab. } \\
\text { Badung* }\end{array}$ & 1 & - & - & 1 \\
\hline 2 & Petang & 6 & 6 & 1 & 13 \\
\hline 3 & Abiansemal & 8 & 4 & 2 & 14 \\
\hline 4 & Mengwi & 9 & 5 & - & 4 \\
\hline 5 & Kuta Utara & 4 & - & - & 2 \\
\hline 6 & Kuta & 1 & - & - & 3 \\
\hline 7 & Kuta Selatan & 3 & 16 & 4 & 52 \\
\hline & \multicolumn{2}{|r|}{ Total } & 32 & & \\
\hline
\end{tabular}

*) 1 orang pejabat fungsional PNS yang paling senior ditugaskan mengkooordinir seluruh penyuluh pertanian (Sumber: Data Kepegawaian Diperpa Badung, data diolah)

Dari data tersebut di atas dapat diketahui bahwa jumlah seluruh penyuluh pertanian sampai dengan akhir Tahun 2018 adalah 52 orang, tetapi khusus untuk penyuluh pertanian dengan status Pejabat Fungsional PNS jumlahnya tinggal 32 orang dikarenakan banyak yang sudah memasuki usia pensiun. Sebagian lagi akan memasuki usia pensiun, seperti terlihat pada Tabel 1.2.

Tabel 1.2

Data Usia Pejabat Fungsional Penyuluh Pertanian PNS Sampai Dengan Bulan Januari 2019

\begin{tabular}{|c|c|c|c|}
\hline No. & $\begin{array}{l}\text { Rentang Usia } \\
\text { (Tahun) }\end{array}$ & Jumlah & Statistik Usia (Tahun) \\
\hline 1 & $36-40$ & 1 & \multirow{5}{*}{$\begin{array}{l}\text { Usia rata-rata }=54 \\
\text { Usia terbanyak }=58\end{array}$} \\
\hline 2 & $41-45$ & 1 & \\
\hline 3 & $46-50$ & 3 & \\
\hline 4 & $51-55$ & 12 & \\
\hline 5 & $56-60$ & 15 & \\
\hline & Jumlah & 32 & \\
\hline
\end{tabular}

(Sumber : Data Kepegawaian Diperpa Badung, data diolah) 
Dari data diatas dapat diketahui bahwa pejabat fungsional penyuluh pertanian yang memasuki Batas Usia Pensiun (BUP) 5 tahun kedepan yaitu dari Tahun 2019 sampai dengan Tahun 2023 dengan rentang usia 56 sampai dengan 60 tahun adalah sebanyak 15 orang, yang artinya dalam 5 tahun jumlah pejabat fungsional penyuluh pertanian tinggal 17 orang saja. Dari data diatas juga dapat diketahui bahwa usia rata-rata pejabat fungsional penyuluh pertanian adalah 54 tahun dan yang paling banyak berusia 58 tahun.Melihat dari jumlah seluruh pejabat fungsional penyuluh pertanian pada Diperpa Badung tidak sebanding dengan wilayah penugasan di Wilayah Kabupaten Badung yang mencakup 6 kecamatan, 62 Desa/Kelurahan dan 120 Subak. Berdasarkan uraian permasalahan diatas, maka penulis menemukan adanya perbedaan antara implementasi dari kebijakan yang seharusnya diterapkan dengan kondisi yang ada di lapangan. Sehingga penulis memfokuskan penelitian pada Manajemen PNS khususnya terhadap pejabat fungsional penyuluh pertanian pada Diperpa Badung, apakah sudah sesuai dengan kebijakan yaitu PP Nomor 11 Tahun 2017 tentang Manajemen PNS.

Dengan memperhatikan latar belakang dan rumusan masalah di atas, maka tujuan khusus penelitian ini, yaitu: 1) Untuk mengetahui bagaimana Implementasi Kebijakan PP Nomor 11 Tahun 2017 tentang Manajemen PNS, khususnya terhadap Pejabat Fungsional Penyuluh Pertanian pada Diperpa Badung. 2) Untuk mengetahui kendala-kendala yang dihadapi dalam Implementasi Kebijakan PP Nomor 11 Tahun 2017 tentang Manajemen PNS, khususnya terhadap Pejabat Fungsional Penyuluh Pertanian pada Diperpa Badung. 3) Untuk mengetahui bagaimana solusi dalam mengatasi kendala Implementasi Kebijakan PP Nomor 11 Tahun 2017 tentang Manajemen PNS, khususnya terhadap Pejabat Fungsional Penyuluh Pertanian pada Diperpa Badung. 4) Untuk mengetahui bagaimana dampak dari Implementasi Kebijakan PP Nomor 11 Tahun 2017 tentang Manajemen PNS, khususnya terhadap Pejabat Fungsional Penyuluh Pertanian pada Diperpa Badung. 


\section{METODE PENELITIAN}

Dalam penelitian ini penulis menggunakan metode penelitian deskriptif kualitatif, penelitian ini dalam mengumpulkan data melakukan kontak langsung dan berhubungan dengan informan secara kontinyu dan wajar. Pengumpulan data dilakukan oleh peneliti secara langsung atau sebagai instrumen pertama dalam mengumpulkan dan menginterpretasikan data. Instrumen penelitian dalam penelitian kualitatif adalah peneliti itu sendiri dan alat-alat yang digunakan seperti : pedoman wawancara, foto/ dokumentasi dan penelitian terhadap dokumendokumen yang ada pada Diperpa Badung.Dalam penelitian ini teknik sampling yang digunakan yaitu nonprobability sampling dengan teknik purposive sampling. Menurut Sugiyono (2016:85) bahwa: "purposive sampling adalah teknik pengambilan sampel sumber data dengan pertimbangan tertentu." Alasan menggunakan teknik purposive sampling adalah karena tidak semua sampel memiliki kriteria yang sesuai dengan fenomena yang diteliti.

Oleh karena itu, penulis memilih teknik Purposive Sampling yang menetapkan pertimbangan-pertimbangan atau kriteria-kriteria tertentu yang harus dipenuhi oleh sampel-sampel yang digunakan dalam penelitian ini.Analisis data merupakan bagian yang penting dalam metode ilmiah karena dengan analisis, data tersebut dapat memberi arti dan makna yang berguna untuk memecahkan masalah penelitian. Penulis juga melakukan penafsiran dan interpretasi data. Penafsiran dan interpretasi data adalah untuk pencarian data yang lebih luas tentang penemuanpenemuan. Dalam menganalisis data, penulis melakukan langkah-langkah sebagai berikut:

1) Reduksi data. Reduksi data merupakan proses pemilihan, pemusatan perhatian pada penyederhanaan, pengabstrakan, tranformasi data kasar yang muncul dari catatan-catatan lapangan. Yaitu dengan menajamkan analisis, menggolongkan atau mengaktegorisasikan kedalam tiap permasalahan dalam uraian singkat, mengarahkan, membuang yang tidak perlu dan mengorganisir data sehingga dapat ditarik kesimpulan dan diverifikasi.Data yang direduksi adalah seluruh data mengenai permasalahan penelitian. 
2) Penyajian Data.Setelah data direduksi maka langkah selanjutnya adalah menyajikan data. Dalam penelitian kualitatif penyajian data bisa dilakukan dalam bentuk uraian singkat, bagan, hubungan antar kategori, flowchart dan sejenisnya.

3) Penarikan Kesimpulan dan Verifikasi. Kesimpulan awal yang diambil masih bersifat sementara, dan akan berubah bila tidak ditemukan bukti-bukti yang valid dan konsisten saat peneliti turun kembali ke lapangan maka dikemukakan kesimpulan yang credibel (dapat dipercaya). Kesimpulan dari penelitian kualitatif diharapkan adalah merupakan temuan baru dari sebelumnya yang pernah ada. Temuan dapat berupa deskripsi atau gambaran suatu objek yang sebelumnya masih belum jelas, sehingga setelah diteliti menjadi jelas.

\section{HASIL DAN PEMBAHASAN}

\subsection{Implementasi PP Nomor 11 Tahun 2017}

Pengaturan Manajemen PNS yang tertuang dalam PP Nomor 11 Tahun 2017 Tentang Manajemen PNS adalah merupakan aturan pelaksanaan atas Pengaturan Manajemen PNS yang terdapat dalam UU Nomor 5 Tahun 2014 tentang ASN. Sebelum UU ini sudah ada UU yang mengatur tentang Manajemen PNS yaitu UU Nomor 8 Tahun 1974 tentang Pokok-Pokok Kepegawaian dan UU Nomor 43 Tahun 1999 tentang Perubahan Atas Undang-Undang Nomor 8 Tahun 1974 tentang Pokok-Pokok Kepegawaian.PNS adalah salah satu dari dua jenis Pegawai ASN, yang lagi satu adalah PPPK (Pegawai Pemerintah dengan Perjanjian Kerja). Perbedaannya adalah kalau PNS berstatus pegawai tetap, memiliki Nomor Induk Pegawai (NIP) secara nasional dan sebagai pembuat kebijakan, sedangkan PPPK diangkat dengan perjanjian kerja, dapat diberikan Nomor Induk Pegawai Perjanjian Kerja dan dapat melaksanakan tugas pemerintahan. PNS memiliki fungsi sebagai pelaksana kebijakan publik, pelayan publik serta perekat dan pemersatu bangsa. 
Ada beberapa aturan baru di dalam PP ini salah satunya adalah terkait Penyusunan dan Penetapan Kebutuhan PNS. Penyusunan Kebutuhan berdasarkan Analisis Jabatan dan ABK sesuai siklus anggaran. Disusun untuk jangka waktu 5 tahun setelah Renstra ditetapkan oleh PPK. Mendukung pencapaian indikator keberhasilan sasaran strategis sebagaimana tertuang dalam rencana strategis instansi masingmasing sebagai turunan dari Rencana Pembangunan Jangka Panjang Nasional dan Rencana Pembangunan Jangka Menengah Nasional. Petunjuk teknis pelaksanaan diatur lebih lanjut dengan Perka BKN. Penetapan kebutuhan PNS secara nasional dan penetapan kebutuhan ada setiap instansi oleh Menteri PANRB setelah memperhatikan pendapat menteri keuangan mendapat persetujuan teknis Kepala BKN. Agenda pembangunan nasional adalah membangun tata kelola pemerintahan yang bersih, efektif, demokratis, dan terpercaya yang di dalamnya memuat penyempurnaan dan peningkatan reformasi birokrasi nasional (RBN).

Sasaran yang ingin diwujudkan adalah meningkatnya kualitas birokrasi dan tata kelola pemerintahan yang baik dalam mendukung peningkatan daya saing dan kinerja pembangunan nasional di berbagai bidang, yang ditandai dengan terwujudnya kelembagaan birokrasi yang efektif dan efisien, meningkatkan kapasitas pengelolaan reformasi birokrasi, diimplementasikannya Undang-Undang ASN (UU ASN) secara konsisten pada seluruh instansi pemerintah, dan meningkatnya kualitas pelayanan publik. Dalam rangka reformasi birokrasi tersebut, salah satu cara dalam penataan SDM (SDM) Aparatur adalah dengan ditetapkannya moratorium penerimaan CPNS. Pelaksanaan moratorium sejak tahun 2015 tersebut dilaksanakan sejalan dengan program reformasi birokrasi yang dicanangkanPresiden Joko Widodo. Kebijakan moratorium atau pembatasan penerimaan CPNS tersebutdimaksudkan untuk memberikan kesempatan kepada instansi untuk menghitung kebutuhan PNS berdasarkananalisis jabatan dan analisis beban kerja, namun tetap memberi kesempatan kepadainstansi untuk melakukan penerimaan CPNS bagi jabatan yang dikecualikan sepanjanginstansi tersebut telah melakukan analisis jabatan dan analisis beban kerja.

Selain itu, moratorium tersebut dimaksudkan agar Pejabat Pembina Kepegawaian Pusat dan Daerah dapat melakukan audit organisasi dan penataan 
SDM Aparatur sesuai dengan arah/rencana strategis pembangunan. Masing-masing instansi diharuskan melakukan redistribusi pegawai secara internal maupun lintas instansi, yang didasarkan pada hasil perhitungan kebutuhan PNS berdasarkan analisis jabatan dan analisis beban kerja. Pemerintah juga perlu melakukan kajian terkait rasio jumlah PNS yang tepat yang dibutuhkan sebanding dengan jumlah penduduk Indonesia. Namun demikian, kebijakan moratorium penerimaan CPNS tersebut tidak berlaku untuk semua jabatan. Hanya jabatan tertentu saja terutama jabatan administrasi, sedangkanjabatan lainnya seperti tenaga kesehatan, guru, dan fungsional lainnya masih dibuka kesempatan dalam pengadaan CPNS. Selama moratorium CPNS diberlakukan, masingmasing instansi diharapkan melaksanakanperhitungan jumlah kebutuhan pegawai perjabatan, redistribusi PNS, serta proyeksi kebutuhan PNS untuk kurun waktu 5 tahun. Dari hasil perhitungan kebutuhan pegawai dimaksud, ternyata masih terdapat kekuranganpegawai pada jabatan-jabatan tertentu antara lain dikarenakan terdapat pegawai yang memasuki BUP dan adanya pembentukan organisasi baru. Oleh karena itu, diperlukan penambahan pegawai baru guna menjaga kualitas pelayanan publik, terutama di sektor pelayanan dasar dengan tetap memperhatikan kemampuan keuangan negara, sehingga pemerintah kemudian perlu untuk melaksanakan pengadaan.

Pengadaan meliputi tahapan perencanaan, pengumuman lowongan, pelamaran, seleksi, pengumuman hasil seleksi, dan pengangkatan dan masa percobaan calon PNS. Pengadaan CPNS dilakukan secara nasional. Panitia Seleksi Nasional Pengadaan CPNS yang diketuai Kepala BKN. Ketentuan lebih lanjut mengenai susunan dan mekanisme kerja Panitia Seleksi Nasional Pengadaan CPNS di atur dengan Peraturan Menteri, sedangkan Petunjuk Teknis Pengadaan CPNS diatur lebih lanjut dengan Perka BKN.Implementasi PP 11 Tahun 2017 terkait pengadaan adalah bahwa pengadaan CPNS diprioritaskan untuk jenis jabatan yang mendukung Nawacita dan RPJMN, yaitu jabatan yang melaksanakan tugas teknis dengan prioritas di bidang pendidikan, kesehatan, penanggulangan kemiskinan, pembangunan infrastruktur, pembangunan poros maritim, ketahanan energi, ketahanan pangan, penegak hukum, dan program dukungan reformasi birokrasi 
serta formasi khusus untuk K/L yang mempunyai pendidikan kedinasan, putra/putri lulusan terbaik/cumlaude, penyandang cacat/disabilitas, serta berprestasi.

Kebijakan pengadaan CPNS ini dilakukan untuk memenuhi kebutuhan pegawai pada jabatan-jabatan strategis (core business) yang mendukung Nawacita sebagai pengganti PNS yang pensiun, serta karena adanya peningkatan beban kerja pada K/L dimaksud. Terdapat perbedaan tentang Pangkat dan Jabatan dalam PP ini dengan UU dan PP yang mengatur tentang Manajemen PNS sebelumnya. Dimana di dalam PP ini Jabatan PNS terdiri dari Jabatan Pimpinan Tinggi (JPT), Jabatan Administrasi (JA) dan Jabatan Fungsional (JF). Dalam PP ini diatur juga tentang Persyaratan dan Pengangkatan Dalam Jabatan, Pelantikan dan Pengambilan Sumpah/Janji, Pemberhentian Dari Jabatan, Tata Cara Pengangkatan Dalam Jabatan, Tata Cara Pemberhentian Dari Jabatan, Larangan rangkap jabatan, Klasifikasi Jabatan, Pengisian Jabatan PNS oleh Prajurit TNI/Anggota Polri.

\subsection{Kendala dalam Implementasi PP Nomor 11 Tahun 2017}

Terdapat beberapa Kendala dalam Implementasi PP Nomor 11 Tahun 2017 terhadap Pejabat Fungsional Penyuluh Pertanian pada Diperpa Badung. Diantaranya adalah bahwa jumlah pejabat fungsional penyuluh pertanian sangatlah kurang jika dibandingkan dengan jumlah kelompok tani baik subak tanah sawah (subak yeh) maupun subak tanah kering (subak abian) dan luas lahan pertanian di Kabupaten Badung, maka penambahan pejabat fungsional penyuluh pertanian pada Diperpa Badung harus segera dilaksanakan sehingga permasalahan kekurangan tenaga penyuluh dapat segera teratasi. Kekurangan pejabat fungsional penyuluh pertanian ini disebabkan begitu banyaknya pejabat fungsional penyuluh pertanian yang pensiun, tetapi tidak diimbangi dengan pengadaan atau pengangkatan pejabat fungsional penyuluh pertanian. Belum lagi sebagian besar penyuluh pertanian yang masih aktif akan memasuki usia pensiun.

Permasalahan lainnya adalah Penetapan BUP bagi pejabat fungsional yang masih membingungkan dikarenakan adanya beberapa peraturan perundangundangan yang isinya sering disalahartikan oleh para pihak antara lain Badan Kepegawaian Negara (BKN), Badan Kepegawaian dan Pengembangan SDM 
(BKPSDM) Kabupaten Badung, Organisasi Perangkat Daerah (dalam hal ini Diperpa Badung), Pejabat Pembina Kepegawaian (PPK), Pejabat yang Berwenang $(\mathrm{PyB})$, dan oleh pejabat fungsional bersangkutan.Permasalahan lainnya terkait pensiun adalah ada beberapa orang penyuluh pertanian malah ada yang sudah diputus gajinya sebelum BUP, padahal sebenarnya yang bersangkutan masih aktif sebagai pejabat fungsional penyuluh pertanian sampai 2 tahun lagi. Hal ini dikarenakan program aplikasi pembayaran gaji secara otomatis memutuskan gaji PNS jika yang bersangkutan sudah berusia 58 tahun.

Selain itu juga terdapat permasalahan terkait dengan mutasi PNS di Lingkungan Pemkab Badung pada saat pembentukan Organisasi Perangkat Daerah yang baru sesuai Peraturan Daerah Kabupaten Badung Nomor 20 Tahun 2016 tentang Pembentukan dan Susunan Perangkat Daerah, dimana ada 2 orang pejabat fungsional penyuluh pertanian yang dimutasi ke Perangkat Daerah lain, sehingga jabatan fungsional yang melekat pada yang bersangkutan otomatis hilang. Hal ini tentu bermasalah dengan proses kenaikan pangkat.Terdapat beberapa permasalahan dalam proses kenaikan pangkat antara lain, bahwa untuk bisa mengajukan usulan kenaikan pangkat ke jenjang pangkat selanjutnya, seorang pejabat fungsional penyuluh pertanian harus memenuhi nilai angka kredit tertentu. Ada beberapa pejabat fungsional yang belum bisa memenuhi angka kredit minimal yang dipersyaratkan untuk jenjang pangkat selanjutnya yang waktunya dibatasi selama 4 tahun sehingga dilaksanakan pemberhentian sementara sebagai pejabat fungsional penyuluh pertanian sampai dengan terpenuhinya nilai angka kredit minimal yang dipersyaratkan untuk dapat diangkat kembali sebagai pejabat fungsional.

Adanya kendala dalam proses kenaikan pangkat khususnya ke jenjang pangkat Pembina Utama Madya golongan ruang IV/d, hal ini dikarenakan belum ada formasi pada Diperpa Badung untuk kebutuhan pejabat fungsional penyuluh pertanian pada jenjang tersebut, padahal angka kredit yang bersangkutan sudah memenuhi syarat minimal. Adanya kendala dalam proses alih jenjang jabatan dari tingkat terampil ke tingkat ahli, dimana untuk bisa mengajukan usulan alih jenjang jabatan, seorang pejabat fungsional harus pernah mengikuti dan mempunyai sertifikat pendidikan dan pelatihan pembentukan penyuluh pertanian tingkat ahli, 
dimana pendidikan dan pelatihan itu dilaksanakan oleh instansi lain dengan kuota peserta terbatas yang biasanya diselengggarakan oleh Balai Besar Pelatihan Pertanian (BBPP) Ketindan Malang.

\subsection{Solusi Mengatasi Kendala dalam Implementasi PP Nomor 11 Tahun 2017}

Diperlukan solusi terhadap Kendala dalam Implementasi PP Nomor 11 Tahun 2017 terhadap Pejabat Fungsional Penyuluh Pertanian pada Diperpa Badung. Salah satu solusi yang sudah dilaksanakan yaitu berupa solusi jangka pendek yaitu dengan mengangkat tenaga kerja non pegawai sebagai tenaga penyuluh pertanian kontrak. Tenaga Kontrak bekerja berdasarkan Keputusan Bupati Badung dengan masa kerja selama 1 Tahun dan dapat diperpanjang. Solusi terhadap permasalahan Penetapan BUP bagi pejabat fungsional adalah agar dengan hal ini, duduk bersama dan sehingga tidak salah tafsir tentang aturan yang terkini tentang BUP. Para pihak yang berkaitan Badan Kepegawaian Negara (BKN), Badan Kepegawaian dan Pengembangan SDM (BKPSDM) Kabupaten Badung, Organisasi Perangkat Daerah (dalam hal ini Diperpa Badung), Pejabat Pembina Kepegawaian (PPK), Pejabat yang Berwenang (PyB), dan oleh pejabat fungsional bersangkutan.

Terkait dengan adanya mutasi PNS di Lingkungan Pemkab Badung pada saat pembentukan Organisasi Perangkat Daerah yang baru sesuai Peraturan Daerah Kabupaten Badung Nomor 20 Tahun 2016 tentang Pembentukan dan Susunan Perangkat Daerah, dimana ada 2 orang pejabat fungsional penyuluh pertanian yang dimutasi ke Perangkat Daerah lain, sehingga jabatan fungsional yang melekat pada yang bersangkutan otomatis hilang. Hal ini tentu bermasalah dengan proses kenaikan pangkat. Untuk kedepannya, jika akan melaksanakan mutasi PNS, pihak yang menerbitkan Surat Keputusan Mutasi yang dalam hal ini BKPSDM Kabupaten Badung harus melakukan koordinasi terlebih dahulu dengan Diperpa Badung.Terdapat beberapa permasalahan dalam proses kenaikan pangkat antara lain, bahwa untuk bisa mengajukan usulan kenaikan pangkat ke jenjang pangkat selanjutnya, seorang pejabat fungsional penyuluh pertanian harus memenuhi nilai angka kredit tertentu. Ada beberapa pejabat fungsional yang belum bisa memenuhi 
angka kredit minimal yang dipersyaratkan untuk jenjang pangkat selanjutnya yang waktunya dibatasi selama 4 tahun sehingga dilaksanakan pemberhentian sementara sebagai pejabat fungsional penyuluh pertanian sampai dengan terpenuhinya nilai angka kredit minimal yang dipersyaratkan untuk dapat diangkat kembali sebagai pejabat fungsional. Hal ini dapat diatasi dengan mempercepat usulan penilaian angka kredit dengan tetap menjaga kuantitas dan kualitas kredit yang diajukan sehingga nilai yang ditetapkan oleh Tim Penilai Angka Kredit cukup untuk proses kenaikan pangkat.

Terkait dengan adanya kendala dalam proses kenaikan pangkat khususnya ke jenjang pangkat Pembina Utama Madya golongan ruang IV/d yang disebabkan belum ada formasi pada Diperpa Badung untuk kebutuhan pejabat fungsional penyuluh pertanian pada jenjang tersebut. Tentunya solusi yang dibutuhkan adalah dengan segera menyusun formasi pada Diperpa Badung untuk kebutuhan pejabat fungsional penyuluh pertanian pada jenjang tersebut dan juga sekaligus menyusun formasi pada Diperpa Badung untuk kebutuhan pejabat fungsional penyuluh pertanian secara lengkap. Solusi untuk permasalahan terkait proses alih jenjang jabatan dari tingkat terampil ke tingkat ahli, dimana untuk bisa mengajukan usulan alih jenjang jabatan, seorang pejabat fungsional harus pernah mengikuti dan mempunyai sertifikat pendidikan dan pelatihan pembentukan penyuluh pertanian tingkat ahli, dimana pendidikan dan pelatihan itu dilaksanakan oleh instansi lain dengan kuota peserta terbatas yang biasanya diselengggarakan oleh Balai Besar Pelatihan Pertanian (BBPP) Ketindan Malang adalah agar Pemkab Badung melalui Diperpa Badung menyediakan anggaran pendidikan dan pelatihan alih jenjang bagi penyuluh pertanian yang dianggarkan melalui APBD Kabupaten Badung, sehingga tidak tergantung dengan kuota perserta diklat dari penyelenggara yang terbatas.

\subsection{Dampak Implementasi PP Nomor 11 Tahun 2017}

Dampak Implementasi PP Nomor 11 Tahun 2017 Tentang Manajemen PNS, adalah berdampak positif, baik bagi pemerintah dalam hal ini Pemkab Badung, bagi perangkat daerah dalam hal ini Diperpa Badung, bagi pegawai secara keseluruhan dan khususnya bagi pejabat fungsional penyuluh pertanian. Dampak 
positifnya antara lain, promosi berjalan teratur, kinerja pegawai meningkat karena ada jaminan pensiun, lancarnya penilaian kinerja, naik pangkat tepat sesuai waktu, promosi bagi pegawai yang berprestasi

\section{PENUTUP}

\subsection{Simpulan}

Berdasarkan hasil penelitian dan pembahasan yang telah diuraikan pada Bab IV, maka dapat diambil kesimpulan sebagai berikut :

1) Implementasi PP Nomor 11 Tahun 2017 tentang Manajemen PNS, khususnya terhadap Pejabat Fungsional Penyuluh Pertanian pada Diperpa Badung, tidak sepenuhnya berjalan dengan baik terdapat karena ditemukan beberapa kendala/permasalahan.

2) Kendala dalam Implementasi PP Nomor 11 Tahun 2017 tentang Manajemen PNS, khususnya terhadap Pejabat Fungsional Penyuluh Pertanian pada Diperpa Badung, antara lain :
a) Jumlah pejabat fungsional penyuluh pertanian yang masih kurang;
b) BUP Pejabat Fungsional banyak disalahtafsirkan;
c) Kendala dalam proses kenaikan pangkat terkait nilai angka kredit;
d) Kendala dalam proses alih jenjang;
e) Mutasi PNS;
f) Belum dibuat formasi JF Penyuluh Pertanian.

3) Solusi untuk mengatasi kendala dalam Implementasi PP Nomor 11 Tahun 2017 tentang Manajemen PNS, khususnya terhadap Pejabat Fungsional Penyuluh Pertanian pada Diperpa Badung, antara lain :

a) Jumlah pejabat fungsional penyuluh pertanian yang masih kurang, diatasi dengan mengangkat tenaga penyuluh pertanian kontrak;

b) BUP Pejabat Fungsional banyak disalahtafsirkan, diatasi dengan koordinasi antar para pihak terkait, sehingga akan timbul satu penafsiran saja;

c) Kendala dalam proses kenaikan pangkat terkait nilai angka kredit, diatasi dengan mempercepat usulan penilaian angka kredit dengan tetap 
menjaga kuantitas dan kualitas kredit yang diajukan sehingga nilai yang ditetapkan oleh Tim Penilai Angka Kredit cukup untuk proses kenaikan pangkat;

d) Kendala dalam proses alih jenjang, agar Pemkab Badung melalui Diperpa Badung menyediakan anggaran pendidikan dan pelatihan alih jenjang bagi penyuluh pertanian yang dianggarkan melalui APBD Kabupaten Badung;

e) Mutasi PNS, Untuk kedepannya, jika akan melaksanakan mutasi PNS, pihak yang menerbitkan Surat Keputusan Mutasi yang dalam hal ini BKPSDM Kabupaten Badung harus melakukan koordinasi terlebih dahulu dengan Diperpa Badung;

f) Belum dibuat formasi JF Penyuluh Pertanian, dengan segera menyusun formasi pada Diperpa Badung untuk kebutuhan pejabat fungsional penyuluh pertanian pada jenjang tersebut dan juga sekaligus menyusun formasi pada Diperpa Badung untuk kebutuhan pejabat fungsional penyuluh pertanian secara lengkap.

4) Dampak Implementasi PP Nomor 11 Tahun 2017 tentang Manajemen PNS, khususnya terhadap Pejabat Fungsional Penyuluh Pertanian pada Diperpa Badung adalah berdampak positif, baik bagi pemerintah dalam hal ini Pemkab Badung, bagi perangkat daerah dalam hal ini Diperpa Badung, bagi pegawai secara keseluruhan dan khususnya bagi pejabat fungsional penyuluh pertanian. Dampak positifnya antara lain, promosi berjalan teratur, kinerja pegawai meningkat karena ada jaminan pensiun, lancarnya penilaian kinerja, naik pangkat tepat sesuai waktu, promosi bagi pegawai yang berprestasi.

\subsection{Saran}

Berdasarkan hasil penelitian yang telah diuraikan pada Simpulan, maka ada beberapa hal yang perlu mendapatkan perhatian sebagai Implementasi PP Nomor 11 Tahun 2017 tentang Manajemen PNS, khususnya terhadap Pejabat Fungsional Penyuluh Pertanian pada Diperpa Badung, bahwa tidak sepenuhnya implementasi tersebut berjalan dengan baik dengan ditemukan beberapa kendala, akan tetapi 
untuk masing-masing kendala tersebut beberapa sudah ada solusi untuk mengatasinya. Untuk itu penulis memberi saran antara lain :

1). Kepada Perangkat Daerah

Diperpa Badung sebagai salah satu organisasi perangkat daerah di Pemkab Badung, tentunya harus tetap melakukan koordinasi dengan organisasi perangkat daerah terkait lainnya baik di Lingkungan Pemkab Badung yaitu BKPSDM, ataupun di luar Lingkungan Pemkab Badung yaitu BKN, sehingga Implementasi PP Nomor 11 Tahun 2017 tentang Manajemen PNS, khususnya terhadap Pejabat Fungsional Penyuluh Pertanian pada Diperpa Badung dapat berjalan dengan baik dan benar.

2). Kepada Pejabat Fungsional

Agar pejabat fungsional dalam hal ini penyuluh pertanian lebih meningkatkan kualitas diri dengan mengikuti pendidikan dan pelatihan pembentukan penyuluh tingkat ahli

3). Kepada Staf Struktural

Terkait kurangnya tenaga penyuluh pertanian dimana banyak penyuluh pertanian yang memasuki usia pensiun, maka diharapkan kepada pegawai struktural khususnya PNS Golongan III untuk alih jabatan menjadi pejabat fungsioanl penyuluh pertanian.

\section{DAFTAR PUSTAKA}

Badan Pusat Statistik Kabupaten Badung. 2018. Kabupaten Badung Dalam Angka Badung Regency In Figures 2018, Cetakan II. Denpasar : CV. Bhineka Karya.

Bali Travel News (laman weg http://bali-travelnews.com/2016/11/11/badung-akanproteksi-pertanian-dari-hulu-sampai-hilir/ diakses tanggal 22 April 2019)

Dokumen Pelaksanaan Anggaran (DPA) Dinas Pertanian dan Pangan Kabupaten Badung Tahun Anggaran 2017, 2018 dan 2019.

Direktorat Jabatan ASN. 2017. Profil Jabatan Fungsional PNS 2017. Jakarta : Badan Kepegawaian Negara.

Harsono, Hanifah. 2002. Implementasi Kebijakan dan Politik. Bandung : Penerbit Remaja Rosdakarya. 
Howlet, Michael and Ramesh, M. 1995. Studying Public Policy. Policy Cycles and Policy Subsystems. Oxsford : Oxford University Press.

Keputusan Bupati Badung Nomor 52/048/HK/2019 tentang Penunjukan Tenaga Kerja Non Pegawai pada Kegiatan Pengadaan Sarana Prasarana Penyuluh.

Keputusan Kepala Diperpa Badung Nomor 25 Tahun 2019 tentang Penetapan Tenaga Harian Lepas Tenaga Bantu Penyuluh Pertanian (THLTBPP) di Kabupaten Badung Tahun Anggaran 2019.

Keputusan Kepala Diperpa Badung Nomor 911 Tahun 2018 tentang Penetapan Wilayah Kerja Penyuluh Pertanian dan Penyuluh Peternakan di Kabupaten Badung Tahun 2019.

Kementerian Pertanian Republik Indonesia (laman web http://www.pertanian.go.id/ home/?show=news\&act=view\&id=2296 diakses tanggal 22 April 2019)

Moeleong, 2000. Metodologi Penelitian Kualitatif. Bandung : PT Kinerja Rosda Kara.

Nasir, Muhammad. 2006. Metode Penelitian. Jakarta : Ghalia Indonesia.

Nasution. 2008. Prosedur Penelitian. Jakarta : Rineka Cipta.

Peraturan Bupati Badung Nomor 69 Tahun 2017 Tentang Jenis Jabatan Fungsional Di Lingkungan Pemkab Badung.

Peraturan Bupati Badung Nomor 78 Tahun 2016 tentang Kedudukan, Susunan Organisasi, Tugas dan Fungsi, serta Tata Kerja Perangkat Daerah.

Peraturan Bupati Badung Nomor 84 Tahun 2016 tentang Uraian Tugas Dinas Daerah Kabupaten Badung.

Peraturan Daerah Kabupaten Badung Nomor 2 Tahun 2001 tentang Organisasi dan Tata Kerja Perangkat Daerah dan Sekretaris Dewan Perwakilan Rakyat Kabupaten Badung.

Peraturan Daerah Kabupaten Badung Nomor 7 Tahun 2008 tentang Pembentukan Organisasi dan Tata Kerja Perangkat Daerah Kabupaten Badung.

Peraturan Daerah Kabupaten Badung Nomor 20 Tahun 2016 tentang Pembentukan dan Susunan Perangkat Daerah. 
Peraturan Menteri Negara Pendayagunaan Aparatur Negara Nomor PER/02/M.PAN/2/2008 tentang Jabatan Fungsional Penyuluh Pertanian dan Angka Kreditnya.

Peraturan Pemerintah Nomor 21 Tahun 2014 tentang Pemberhentian PNS Yang Mencapai BUP Bagi Pejabat Fungsional.

Peraturan Pemerintah Nomor 11 Tahun 2017 tentang Manajemen PNS.

Peraturan Presiden Nomor 16 Tahun 2013 tentang Tunjangan Jabatan Fungsional Penyuluh Pertanian, Pengendali Organisme Pengganggu Tumbuhan, Pengawas Benih Tanaman, Pengawas Bibit Ternak, Medik Veteriner, Paramedik Veteriner, dan Pengawas Mutu Pakan.

Safitri, Lia. 2016. Implementasi Kebijakan E-Formasi SDM Aparatur dalam Rekrutmen Pegawai di Pemerintah Kota Surabaya. Surabaya : Universitas Airlangga.

Setiawan, Guntur. 2004. Implementasi Dalam Birokrasi Pembangunan. Bandung : Remaja Rosdakarya Offset.

Setioutomo, Bambang. 2008. Evaluasi Implementasi Manajemen PNS Di Lingkungan Direktorat Ajudan Jenderal Angkatan Darat Tahun 2008 [Tesis]. Bandung : Instutut Teknologi Bandung.

Siagian, P. Sondang. 2005. Fungsi-Fungsi Manajerial. Jakarta : Bumi Aksara.

Suharno, 2010. Dasar-dasar Kebijakan Publik. Yogyakarta : Alfabeta.

Solichin, Abdul Wahab. 2001. Analisis Kebijaksanaan. Jakarta : PT. Bumi Aksara.

Sunggono. 1994. Pemberdayaan Masyarakat dan Jaringan Pengamanan Sosial. Jakarta : Gramedia Pustaka Utama.

Sugiyono. 2009. Metode Penelitian Bisnis. Bandung : CV. Alfabeta.

Thomas Dye, R. 2002. Understanding Public Policy, Tenth edition. London : Prenfice-Hall.

Undang-Undang Nomor 5 Tahun 2014 tentang ASN.

Undang-Undang Nomor 23 Tahun 2014 tentang Pemerintahan Daerah.

Uchjana, Effendy Onong. 2001. Dinamika Komunikasi. Bandung : Penerbit Remaja Rosdakarya. 
Van Meter dan Van Horn. Implementation Public Policy. Washington DC: Congressional Quarter Perss.

Wilian N. Dunn, 2000. Pengamatan Analisis Kebijakan Publik. Yogayakarta : Gajah Mada University Press.

Wibawa, dkk. 2006. Evaluasi Kebijakan Publik. Jakarta : Raja Grafindo Persada. 